http://dx.doi.org/10.4322/rbcv.2016.047

\title{
Rickettsia spp., Ehrlichia spp. e Anaplasma spp. em carrapatos de vida livre nas mesorregiões Sul Fluminense e Metropolitana do Rio de Janeiro, RJ*
}

\author{
Rickettsia spp., Ehrlichia spp. and Anaplasma spp. in free-living ticks of \\ mesoregions South Fluminense and Metropolitan area of Rio de Janeiro, RJ
}

\author{
Gustavo Nunes de Santana Castro, ${ }^{* *}$ Andrea Kill Silveira, ${ }^{* *}$ Laura Ribeiro, ${ }^{* *}$ Matheus Dias Cordeiro, ${ }^{* *}$ \\ Adevair Henrique da Fonseca, ${ }^{* *}$ Adivaldo Henrique da Fonseca**
}

\begin{abstract}
Resumo
Os carrapatos são ectoparasitas obrigatórios e vetores de agentes patogênicos como bactérias, parasitos e vírus. O presente estudo teve como objetivo identificar a presença de bactérias dos gêneros Rickettsia, Ehrlichia e Anaplasma em carrapatos de vida livre coletados em cinco áreas, localizadas nas mesorregiões Sul Fluminense e Metropolitana do Rio de Janeiro. Foram coletados 9.353 carrapatos distribuídos em 372 pools. A análise dos dados pelo método PCR-RFLP indicou que as bandas verificadas na análise eram de Rickettsia bellii em $0,25 \%$ dos carrapatos coletados de duas áreas. A pesquisa molecular para os gêneros Ehrlichia e Anaplasma revelou resultados negativos para ambos os gêneros. A presença de genoma de $R$. bellii em carrapatos sugere a importância da execução de novas pesquisas com o intuito de entender a epidemiologia dos agentes estudados na região.
\end{abstract}

Palavras-chave: ixodídeos, Rickettsia bellii, Rickettsiales.

\begin{abstract}
Ticks are obligate ectoparasites and vectors of several bacterial, parasitic and viral pathogens. This study aimed to identify bacteria of the Rickettsia, Ehrlichia and Anaplasma genera in free-living ticks, collected in five areas located in both South Fluminense and Metropolitan mesoregions of Rio de Janeiro state. We collected a total of 9,353 ticks which were distributed in 372 pools. Data analysis using the PCR-RFLP method showed that the bands observed in the analysis are of the type Rickettsia bellii. The positivity level to $R$. bellii found in this study was $0.25 \%$. The molecular search for Ehrlichia and Anaplasma genera revealed negative results for both genera. The presence of Rickettsiae DNA in the Rocky Mountain Spotted Fever group in ticks suggests the importance of undertaking new research in order to understand the epidemiology of the agents.
\end{abstract}

Keywords: ixodids, Rickettsia bellii, Rickettsiales.

\section{Introduction}

Ticks are important vectors of pathogens, including bacteria, viruses, and protozoa (Dantas-Torres et al., 2012). Ticks of the genera Argas, Amblyomma, Dermacentor, Haemaphysalis, Hyalomma, Ixodes and Rhipicephalus were described parasitizing human beings (Otranto et al., 2014). When searching for the presence of blood parasites, these authors detected pathogens of the genera Rickettsia, Anaplasma, Borrelia and Babesia, thus demanding the importance of ticks as vectors of important zoonosis. Some pathogens can influence a tick's gene expression, demonstrating a molecular interaction between tick's species and the pathogens transmitted by them (Liu \& Bonnet, 2014).

The Rocky Mountain Spotted Fever Group rickettisiae are transmitted by ticks and may cause severe human infectious diseases and transmit agents of human tick-borne rickettsiosis in Brazil, originated from wildlife hosts (Szabó et al., 2013).
Whatever the origin of pathogenic Rickettsia, the human activities can be responsible for the amplification of both wildlife hosts and tick infections, and may be also associated to factors ranging from natural environment to human dwellings. Nonetheless, acknowledgment of the ecological background of each rickettsiosis is a major step to provide diagnosis, treatment and preventive measures (Szabó et al., 2013). According to Parola et al. (2013), microbial isolation and animal transmission studies of rickettisiae are important tools to better understand the role of ticks as potentials reservoirs and vectors for both pathogenic and species of unknown pathogenicity.

Canine monocytic ehrlichiosis has a worldwide distribution and is a highly prevalent disease in Brazil, where Ehrlichia canis revealed substantial genetic diversity (Aguiar et al., 2013). Canine granulocytic ehrlichiosis is caused by either Ehrlichia ewingii or Anaplasma phagocytophilum. Anaplasma phagocytophilum has been found throughout the world in large quantities of vertebrate hosts (e.g., dogs, ruminants, humans and rodents) and is

\footnotetext{
*Recebido em 18 de agosto de 2016 e aceito em 7 de outubro de 2016.

**Universidade Federal Rural do Rio de Janeiro, Instituto de Veterinária, Departamento de Epidemiologia e Saúde Pública, Seropédica, RJ - Brasil.

Autor para correspondência: E-mail: adivaldofonseca@yahoo.com.
} 
vectored largely by the Ixodes species (Yabsley et al., 2008). In addition, Santos et al. (2013) demonstrated the presence of $A$. phagocytophilum in $6.03 \%$ of 398 blood samples from dogs in the state of Rio de Janeiro, as well as its presence in Amblyomma sculptum (A. cajennense complex) and Rhipicephalus sanguineus naturally parasitized.

This study aimed to identify the presence of bacteria belonging to the genera Rickettsia, Ehrlichia and Anaplasma in free-living ticks collected in five areas located in both South Fluminense and Metropolitan mesoregions of Rio de Janeiro state, Brazil.

\section{Material and methods}

The ticks assessed in this study were collected in the State of Rio de Janeiro from October 2009 to August 2011, as described by Silveira and Fonseca (2013). The collections in the Itatiaia National Park - PNI and National Forest Mario Xavier FLONA were authorized by SISBIO 16622-1. The activities in military areas, like the Navy of Brazil and the Brazilian Army, were authorized by their respective commands. The ADN samples extracted were submitted to PCR and agarose gel electrophoresis at the Parasitic Diseases Laboratory and the Molecular Biology Multi-User Laboratory of the Federal Rural University of Rio de Janeiro.

Ticks were collected using three sampling techniques: 1) $\mathrm{CO} 2$ chemical trap, 2) flannel drag nets and 3) from the clothing of the researchers who participated in the research (Silveira \& Fonseca, 2011). For the specific identification of tick's dichotomous keys were used, according to Aragão \& Fonseca (1961) and Battesti et al. (2006). Adults were identified as species, and immature stages as gender. The ticks were pooled according to the capture areas, relocated in polypropylene tubes and frozen at $-20^{\circ} \mathrm{C}$ until extraction of their nucleic acids.

ADN extraction was performed with protocol phenol/phenol-chloroform, according Costa Santolin et al. (2013). To research the genus Rickettsia a PCR was carried out in order to amplify the portion of $549 \mathrm{bp}$ of the $h$ trA gene (17kDa), using the $17 \mathrm{~K}-5$ and $17 \mathrm{~K}-3$ primers and the portion of $834 \mathrm{bp}$ of the gltA gene (Citrate synthase), using CS-239 and CS-1069 primers (Labruna et al., 2004a).

Positive samples in the two reactions were subjected to a new PCR with primers that identified Rickettsia of the Rocky Mountain Spotted Fever group. For amplification of the 532 bp portion of the ompA, $\operatorname{Rr} 190,70 p$ and $\operatorname{Rr} 190,602 n$ genes, primers were used (Labruna et al., 2004a). "Amplicons" derived from positive tick's samples in conventional PCR assays for Rickettsia were digested using the restriction enzymes HindIII, Msp1 and Rsal (New England Biolabs), selected based on the analysis of digestion in silico (Santolin et al., 2013).
To study the Ehrlichia genus, we used the $d s b 330$ and $d s b 720$ primers for the first amplification, which had a product with 401 bp; and $d s b 380$ and $d s b 720$ primers were used for the second amplification, as well as the amplified product size $349 \mathrm{bp}$, according to Aguiar et al. (2014). In the molecular research of the genus Anaplasma, primers ge3a and ge10r primary PCR were used, whose product is $932 \mathrm{bp}$ (Massung et al., 1998). For the secondary PCR, ge9f and ge2 primers were used, whose target is the $16 \mathrm{~S}$ rRNA gene with $546 \mathrm{bp}$. We analyzed all these products by electrophoresis on agarose gel at $1.5 \%$ to confirm the size amplicon reached by comparison with a ADN-based molecular weight marker (GeneRuler 100 bp ADN Ladder, produto \# SM024, Thermo Scientific). The bands were visualized with the aid of transillumination, and the photographic record was carried out with a specific electronic device.

\section{Results}

Nine thousand three hundred and fifty-three specimens were analyzed, distributed in 372 samples according to their taxonomic classification, evolutionary stage, area and year of collection. Each pool contained 50 larvae, 20 nymphs and one adult. This total consisted of 7,273 larvae of Amblyomma, one larva of R. (B.) microplus, 1,952 nymphs of Amblyomma, 120 adult $A$. sculptum, four adults and three adult Amblyomma brasiliense and Amblyomma dubitatum (Table 1).

Table 1: Ticks analyzed by molecular biology, separated by evolutionary stage, genus, species and sex, collected between October 2009 and August 2011 in five institutional areas in the state of Rio de Janeiro, Brazil

\begin{tabular}{|c|c|c|c|c|c|c|}
\hline Genus/Specie /Gender & PNI & Marambaia & FLONA & DCMun & UFRRJ & Total \\
\hline Amblyomma spp. - larvas & 0 & 544 & 538 & 4463 & 1728 & 7273 \\
\hline Amblyomma spp. - ninfas & 6 & 445 & 528 & 295 & 678 & 1952 \\
\hline Amblyomma sculptum - $\widehat{\jmath}$ & 0 & 14 & 11 & 16 & 19 & 60 \\
\hline Amblyomma sculptum - $q$ & 0 & 12 & 11 & 31 & 6 & 60 \\
\hline Amblyomma brasiliense $-\widehat{O}$ & 2 & 0 & 0 & 0 & 0 & 2 \\
\hline Amblyomma brasiliense - $q$ & 2 & 0 & 0 & 0 & 0 & 2 \\
\hline Amblyomma dubitatum - $\widehat{\jmath}$ & 0 & 0 & 0 & 0 & 0 & 0 \\
\hline Amblyomma dubitatum - $q$ & 0 & 0 & 2 & 1 & 0 & 3 \\
\hline Rhipicephalus microplus - larvas & 0 & 0 & 0 & 0 & 1 & 1 \\
\hline Total & 10 & 1015 & 1090 & 4806 & 2432 & 9353 \\
\hline
\end{tabular}

PNI: Itatiaia National Park; Marambaia: Marambaia Sandbank; FLONA: National Forest Mário Xavier; DCMun: Central Ammunition Depot; UFRRJ: Federal Rural University of Rio de Janeiro.

Two samples were positives: one comes from three larvae of Amblyomma from FLONA and one from a pool of 20 nymphs of Amblyomma sp. from Marambaia. When the samples were subjected to $P C R$ reaction using primers specific to rickettsiae of the Rocky Mountain Spotted Fever group (GFM) (ompA), was showed that they were negative for this group of Rickettsia. Data analysis by Restriction Fragment Length Plymorfism Polimerase Chain Reaction (RFLP-PCR) method showed that the bands observed in the analysis were similar to the pattern expected for Rickettsia bellii, whose positivity was $0.25 \%$. 


\section{Discussion}

Rickettsia bellii has already been identified in several species of ticks in Brazil (Estrada et al., 2006; Horta et al., 2007; Labruna et al., 2004a, 2004b; Mclntosh et al., 2015). In a Brazilian native people's reservation in the state of Mato Grosso, the circulation of $R$. bellii in Amblyomma sp. larvae and A. sculptum adult was recorded by Moura-Martiniano et al. (2014). In areas of occurrence of Brazilian Spotted Fever (BSF) in the state of Mato Grosso, Lopes et al. (2014) confirmed the presence of $R$. bellii in a specimen of $A$. dubitatum, suggesting the importance of these species of rickettsiae as a potential threat for the native local population and for differential diagnostic of BSF, nevertheless of unknown pathogenicity for humans.

Competition for ecological niche between rickettsia species within the tick has been previously reported, resulting in the fact that once infected by a rickettsia, a tick is refractory to a second species (Burgdorfer et al., 1980). It was experimentally observed that in an artificially infected tick, a second species of Rickettsia had its transovarial transmission inhibited (Macaluso et al., 2002).
Thus, the presence of Rickettsia Bellii can inhibit, for example, an infection by other rickettsiae of known pathogenicity, such as Rickettsia rickettsii and Rickettsia parkeri in ticks.

In this study, in both areas where the circulation of $R$. bellii was found, there was the presence of capybaras, whose are very important in the epidemiology of the Brazilian Spotted Fever. This mammal acts as the primary host and amplifier and vectors tick such as $A$. sculptum and $A$. dubitatum (Souza et al., 2009), $R$. belli has the potential to induce immune response in mammals, either by natural or experimental infection (Horta et al., 2010), which is exciting for a thorough investigation into its possible pathogenicity to vertebrate hosts.

Circulation of organisms belonging the genus Rickettsia in the areas studied was found, but Ehrlichia and Anaplasma were not diagnosed. The presence of the genome of $R$. bellii in free-living ticks reinforces the need to elucidate the importance in their epidemiology, and suggests the importance of undertaking new research in order to understand the epidemiology of this specie of rickettsia.

\section{Acknowledgements}

We thank Professor Douglas McIntosh for helping with the molecular analysis; to Iwine Faria to conduct the taxonomic classification of the nymphs studied. We also thank CAPES and FAPERJ for the financial support.

\section{References}

AGUIAR, D.M.; ZHANG, X; MELO, A.L.T.; PACHECO, T.A.; MENESES, A.M.C.; ZANUTTO, M.S.; HORTA, M.C.; SANTARÉM, V.A.; CAMARGO, L.M.A.; MCBRIDE, J.W.; LABRUNA, M.B. Genetic diversity of Ehrlichia canis in Brazil. Veterinary Microbiology, v. 164, p. 315-321, 2013.

AGUIAR, D.M.; ZILIANI, T.F.; ZHANG, X.; MELO, A.L.; BRAGA, I.A.; WITTER, R.; FREITAS, L.C.; RONDELLI, A.L.; LUIS, M.A.; SORTE, E.C.; JAUNE, F.W.; SANTAREM, V.A.; HORTA, M.C.; PESCADOR, C.A.; COLODEL, E.M.; SOARES, H.S.; PACHECO, R.C.; ONUMA, S.S.; LABRUNA, M.B.; MCBRIDE, J.W. A novel Ehrlichia genotype strain distinguished by the TRP36 gene naturally infects cattle in Brazil and causes clinical manifestations associated with ehrlichiosis. Ticks Tick Borne Diseas, v. 5, p. 537544, 2014.

ARAGÃO, H.; FONSECA, F.D. Notas de ixodologia: VIII. Lista e chave para os representantes da fauna ixodológica brasileira: notas de ixolodologia. Memórias do Instituto Oswaldo Cruz, v. 59, p. 115-129, 1961.

BATTESTI, D.M.B.; ARZUA, M.; BECHARA, G.H. Carrapatos de importância médico-veterinária da região neotropical: um guia ilustrado para identificação de espécies. In: Carrapatos de importância médico-veterinária da região neotropical: um guia ilustrado para identificação de espécies, Vox/ICTTD-3/Butantan, 2006.

BURGDORFER, W.; HAYES, S.; MAVROS, A. Nonpathogenic rickettsiae in Dermacentor andersoni: a limiting factor for the distribution of Rickettsia rickettsii. Rickettsiae and rickettsial diseases, 1980.

DANTAS-TORRES, F.; CHOMEL, B.B.; OTRANTO, D. Ticks and tick-borne diseases: a One Health perspective. Trends in Parasitology, v. 28, p. 437-446, 2012.
ESTRADA, D.A.; SCHUMAKER, T.T.S.; SOUZA, C.E.D.; RODRIGUES NETO, E.J.; LINHARES, A.X. Detecção de riquétsias em carrapatos do gênero Amblyomma (Acari: Ixodidae) coletados em parque urbano do município de Campinas, SP. Revista da Sociedade Brasileira de Medicina Tropical, v. 39, p. 68-71, 2006.

HORTA, M.C.; LABRUNA, M.B.; PINTER, A.; LINARDI, P.M.; SCHUMAKER, T.T.S. Rickettsia infection in five areas of the state of São Paulo, Brazil. Memórias do Instituto Oswaldo Cruz, v. 102, p. 793-801, 2007.

HORTA, M.C.; SABATINI, G.S.; MORAES-FILHO, J.; OGRZEWALSKA, M.; CANAL, R.B.; PACHECO, R.C.; MARTINS, T.F.; MATUSHIMA, E.R.; LABRUNA, M.B. Experimental infection of the opossum Didelphis aurita by Rickettsia felis, Rickettsia bellii, and Rickettsia parkeri and evaluation of the transmission of the infection to ticks Amblyomma cajennense and Amblyomma dubitatum.(Report). Vector-Borne and Zoonotic Diseases, v. 10, p. 959, 2010.

LABRUNA, M.; WHITWORTH, T.; HORTA, M.; BOUYER, D.; MCBRIDE, J.; PINTER, A.; POPOV, V.; GENNARI, S.; WALKER, D. Rickettsia species infecting Amblyomma cooperi ticks from an area in the state of Sao Paulo, Brazil, where Brazilian spotted fever is endemic. Journal Clinical Microbiology, v. 42, p. 90-98, 2004a.

LABRUNA, M.B.; WHITWORTH, T.; BOUYER, D.H.; MCBRIDE, J.; CAMARGO, L.M.A.; CAMARGO, E.P.; POPOV, V.; WALKER, H.D. Rickettsia bellii and Rickettsia amblyommii in Amblyomma ticks from the State of Rondonia, Western Amazon, Brazil. Journal of Medical Entomology, v. 41, p. 1073-1081, 2004b.

LIU, X.Y.; BONNET, S.I. Hard Tick Factors Implicated in Pathogen Transmission. PLoS Neglected Tropical Diseases, v. 8, p. 5, 2014. 
LOPES, L.B.; GUTERRES, A.; ROZENTAL, T.; OLIVEIRA, R.C.; MARES-GUIA, M.A.; FERNANDES, J.; FIGUEREDO, J.F.; ANSCHAU, I.; JESUS, S.; AB, V.A.; SILVA, C.V.; VIA, A.V.G.M.; BONVICINO, C.R.; D'ANDREA, P.S.; BARREIRA, J.D.; LEMOS, E.R.S. Rickettsia bellii, Rickettsia amblyommii, and Laguna Negra hantavirus in an Indian reserve in the Brazilian Amazon. Parasit Vectors, v. 7, p. 191, 2014.

MACALUSO, K.R.; SONENSHINE, D.E.; CERAUL, S.M.; AZAD, A.F. Rickettsial infection in Dermacentor variabilis (Acari: Ixodidae) inhibits transovarial transmission of a second Rickettsia. Journal of Medical Entomology, v. 39, p. 809-813, 2002.

MASSUNG, R.F.; SLATER, K.; OWENS, J.H.; NICHOLSON, W.L.; MATHER, T.N.; SOLBERG, V.B.; OLSON, J.G. Nested PCR assay for detection of granulocytic ehrlichiae. Jounal of Clinical Microbiology, v. 36, p. 1090-1095, 1998.

MCINTOSH, D.; BEZERRA, R.A.; LUZ, H.R.; FACCINI, J.L.H.; GAIOTTO, F.A.; GINÉ, G.A.F.; ALBUQUERQUE, G.R. Detection of Rickettsia bellii and Rickettsia amblyommii in Amblyomma longirostre (Acari: Ixodidae) from Bahia state, Northeast Brazil. Brazilian Journal of Microbiology, v. 46, p. 879-883, 2015.

MOURA-MARTINIANO, N.O.; MACHADO-FERREIRA, E.; CARDOSO, K.M.; GEHRKE, F.S.; AMORIM, M.; FOGACA, A.C.; SOARES, C.A.; GAZETA, G.S.; SCHUMAKER, T.T. Rickettsia and vector biodiversity of spotted fever focus, Atlantic rain forest biome, Brazil. Emerging Infectous Diseases, v. 20, p. 498-500, 2014.

OTRANTO, D.; DANTAS-TORRES, F.; GIANNELLI, A.; LATROFA, M.S.; CASCIO, A.; CAZZIN, S.; RAVAGNAN, S.; MONTARSI, F.; ZANZANI, S.A.; MANFREDI, M.T. Ticks infesting humans in Italy and associated pathogens. Parasit Vectors, v. 7, p. 328, 2014.

PAROLA, P.; PADDOCK, C.D.; SOCOLOVSCHI, C.; LABRUNA, M.B.; MEDIANNIKOV, O.; KERNIF, T.; ABDAD, M.Y.; STENOS, J.; BITAM, I.; FOURNIER, P.E.; RAOULT, D. Update on Tick- Borne Rickettsioses around the World: a Geographic Approach. Clinical Microbiology Review, p. 657-702, 2013.
SANTOLIN, I.D.A.C.; FAMADAS, K.M.; MCINTOSH, D. Detecção e identificação de espécies de Rickettsia em carrapatos coletados de aves silvestres no Brasil pela PCR-RFLP, 35(Supl.2):68-73, 2013. Revista Brasileira de Medicina Veterinária, v. 35, p. 5, 2013.

SANTOS, H.A.; THOME, S.M.; BALDANI, C.D.; SILVA, C.B.; PEIXOTO, M.P.; PIRES, M.S.; VITARI, G.L.; COSTA, R.L.; SANTOS, T.M.; ANGELO, I.C.; SANTOS, L.A.; FACCINI, J.L.; MASSARD, C.L.; THOME, S.M.G.; VITARI, G.L.V.; FACCINI, J.L.H. Molecular epidemiology of the emerging zoonosis agent Anaplasma phagocytophilum (Foggie, 1949) in dogs and ixodid ticks in Brazil.(Research)(Report). Parasites \& Vectors, v. 6, p. 348, 2013.

SILVEIRA, A.K.; FONSECA, A.H. Caracterização de ambientes com potencial para ocorrência de carrapatos transmissores de agentes patogênicos para humanos. Boletin do Parque Nacional do Itatitaia, v. 1, p. 87, 2011.

SILVEIRA, A.K.; FONSECA, A.H. Distribuição, diversidade e sazonalidade de carrapatos em ambientes institucionais com diferentes graus de intervenção humana no estado do Rio de Janeiro, Brasil. Revista Brasileira de Medicina Veterinária, v. 35 , p. 12, 2013.

SOUZA, C.E.; MORAES-FILHO, J.; OGRZEWALSKA, M.; UCHOA, F.C.; HORTA, M.C.; SOUZA, S.S.; BORBA, R.C.; LABRUNA, M.B. Experimental infection of capybaras Hydrochoerus hydrochaeris by Rickettsia rickettsii and evaluation of the transmission of the infection to ticks Amblyomma cajennense. Veterinary parasitology, v. 161, p. 116-121, 2009.

SZABÓ, M.P.J.; PINTER, A.; LABRUNA, M.B. Ecology, biology and distribution of spotted- fever tick vectors in Brazil. Frontiers in cellular and infection microbiology, v. 4, 2013. 